葉形態形成のメカニズム解明に向けて

塚谷 裕一

東京大学 分子細胞生物学研究所

（テ113 東京都文京区弥生 1-1-1）

\title{
Hirokazu TSUKAYA: Progress towards an understanding of the mechanisms of leaf morphogenesis.
}

Institute of Molecular and Cellular Biosciences, The University of Tokyo

1-1-1 Yayoi, Bunkyo-ku, Tokyo 113, JAPAN

\section{要旨}

葉の形態形成のように、現象論的に複雑な生命現象について、その仕組みを理 解するためには、形態形成の過程を時間、空間、遺伝子の 3 つの次元に展開する 発生遺伝学という手法は、きわめて有効である。しかし、形態と遺伝子とは遠く 乘離しているため、形態学と遺伝学のみを組み合わせた発生遺伝学だけでは、そ の理解はすぐに限界に到達してしまう。そこで発生遺伝学は、必然的に生理学や 生化学、生物物理学の手法をも積極的に取り入れることが求められる。さらに、 形態形成の進化までを視点にいれれば、研究は必然的に隣接領域との複合的なも のとならざるを得ない。葉の形態形成の仕組みを理解するため、現在とりうる研 究手法の現状と、今後の展望について考察した。

\begin{abstract}
The appearance of the techniques of developmental genetics is one of the most powerful strategies in efforts to understand the mechanisms of complex biological phenomena, such as leaf morphogenesis.

However, developmental genetic analysis alone is insufficient for detailed characterization of the mechanisms that control such morphogenesis. Thus, physiological, biochemical, and biophysical methods must also be applied to the analysis of morphogenetic pathways. An overview of past and potential future studies of leaf morphogenesis is presented.
\end{abstract}

キーワード： 発生遺伝学、葉形態形成、隣接領域 
はじめに

葉、特に双子葉植物の葉の形態形成は、最終的に完成する器官の外形が単純であるのに 比して、驚くほど複雑で、解剖学的な解析のみでは十分な理解に達することが難しい。そ こで近年、私たちはモデル植物を使って、発生遺伝学の手法を導入し、その形態形成の仕 組みを理解しようと試みている。その具体的な成果の一部は、本誌を含め、すでに他に発 表してきた(Tsukaya et al., 1994; Tsukaya, 1995a; Tsukaya 1995b; Tsukaya et al., 1995; Tsuge et al., 1996)ので、ここでは研究全体の理念的な部分について議論してみたい。

背景

葉の形態形成を理解しようという試みは、古くから解剖学的な手法によって行なわれて きた。しかし、先に述べたように葉の形態形成という現象は、解剖学的にはかなり複雑で あるという指摘がなされる(Avery, 1933; Maksymowych, 1963; Poethig and Sussex,1985) にいたり、あまり理解が進んでいなかった。

ここで解剖学という研究手法について考えてみると、これは、かたちの成り立ちを時間 と空間に分けて捉えようとする学問である（図 1)。葉の形態形成の理解にとって、解剖 学の限界とは、形態形成という現象を時間軸と空間軸の 2 つの軸だけで展開しようとする ところにある。逆に言うと、双子葉植物の葉の形 態形成では、同じ時間、同じ場所で性質の異なる 生物現象が混在しているところに、解剖学にとっ ての難しさがあるわけである。実際に何が起きて いるのかといえば、それは細胞・組織の分化であ り、細胞の分裂であり、また伸長である。そして それらを内包するかたちで行なわれている器官の 分化である。

そこで、この複雑に入り組んだ生物現象を解き あかすためには、時間・空間とは別の次元を持ち 込むのが有効ではないか、という立場が生じる。 そのひとつが、私たちのとっている発生遺伝学と いう手法である。

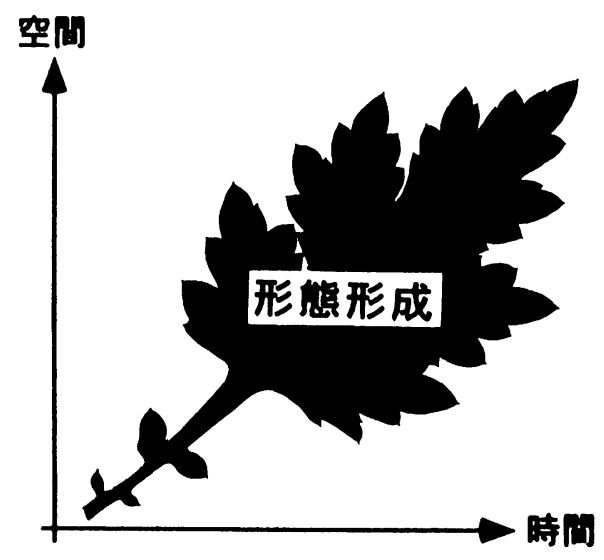

発生遺伝学では、時間と空間という $2 つ の$ 軸に 加え、遺伝的な素過程を導入する。具体的には、 形態に関連した突然変異体を扱うか、特定の遺伝

子の発現を人工的に操作してみて、その形態 に及ほす影響を解析する。そうすることによって、2 次元で展開してみていた現象を、い わば 3 次元的に展開することができるわけである（図 2）。

それを実際に研究の場で行なうためには、遺伝学が容易に適用できる材料が必要となる。 ほかの器官に先行して進んでいる花の形態形成の仕組みの理解が、もっぱらアラビドプシ スとキンギョソウで行なわれているのは、この 2 種の植物が、特に分子遺伝学的実験手法 
に適していたからである。

まずキンギョソウの利点をあげれば、まず第 1 に、園芸植物として花の形や色彩、花序の形 に関する変異体が古くより蓄積していたこと、 第 2 に、それらの変異体には、内在性のトラン スポゾンによって引き起こされたものが多かっ たこと、第 3 に、遺伝学的な実験が容易な植物 であったこと、等があげられよう。第 2 の点は 非常に有効で、これまでキンギョソウから単離 されてきた遺伝子の多くは、このトランスポゾ ン・タッギングによって同定されている。現在 では活発に転移するトランスポゾンを持つ系統 をつかって、新たに目的の遺伝子に対するタッ ギングを行なう系も確立している。

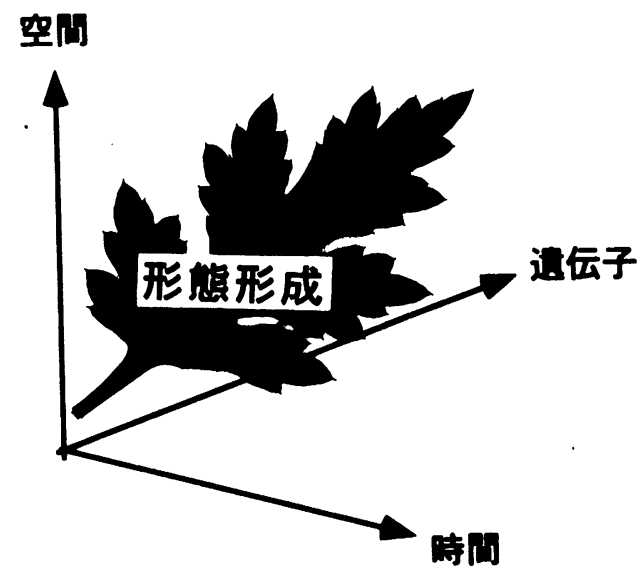

いっぽう、アラビドプシス（シロイヌナズナ Arabidopsis thaliana (L.) Heynh.) が近年、遺伝学 図 2 発生遺伝学は遺伝子という軸をたてる。 的解析のためのモデル植物として用いられるよ

うになってきた背景には、2つの側面があったと思われる。もちろん、ゲノムサイズが(知 られている限り）種子植物中最小であること、ライフサイクルが短いこと、小型で場所を とらないこと、遺伝学的解析が容易であること、などの植物そのものの利点(Meyerowitz and Pruitt, 1985)によるところも大きい。しかしそれに加えて大きな要素となったのは、国 際的な研究協力体制にもとづいてアラビドプシスに関する研究環境が整備されてきたこと であろう。その環境の整備とは、種子・ゲノムバンクの設立であり、データベースの構 築・整備、アラビドプシスに関する国際会議、電子メールを通じての情報交換ネットワー ク等々である。たとえば、アメリカ・オハイオにあるストックセンターには、実に多数の、 変異体を中心とした種子バンクがあり、請求に応じて無料で配布事業を行なっている。遺 伝子クローンも同様である。データベースも、研究論文から変異体、実験方法、研究者の 連絡先など、さまざまな情報を集めて、操作性もよい。このような研究環境の整備のもと、 発生遺伝学はアラビドプシスというモデル植物を相手に、その持てる力をフルに近く発揮 できるようになった。

変異体から遺伝子へ

さてそれでは、発生遺伝学的手法をとるとすれば、具体的にどのようなやり方が考えら れるだろうか。先に触れたとおり、発生遺伝学的解析に、2 通りの方向がある。1つは、 形態に関連した突然変異体を出発点に、その原因遺伝子を単離するという方向。もう1つ は、特定の遺伝子の発現を人工的に操作してみて、その形態に及ほす影響を解析する、と いうものである。実際の研究の方向は、前者の、変異体から遺伝子へという流れをとるこ とが多い。それは形態形成を司る遺伝子の性質が、まだ予測しがたいためであり、またア ラビドプシスにおいては、目標遺伝子を人工的に破壊する系が実用レベルに達していない 
ためである。そこで、まずは注目する形態形質について異常を示す変異体を単離し、そこ からそれに対応する遺伝子を単離する、という順番となる。この過程においても、研究材 料は選ばれてこざるを得ない。さまざまな実験手法が確立しているアラビドプシスでさえ、 この過程は試行錯誤を要する段階である。

現在最もよく用いられている手法は、T-DNAタッギングであるが、最近、ゲノムライブ ラリーの染色体上の位置関係について情報量が増大したため、mapp-based cloningも現実的 となってきた。近い将来、突然変異体についての正確な遺伝子座のマップ位置を決定すれ ば、その情報から直接、対応する遺伝子の単離ができるようになるであろう。

遺伝子の機能

さて、単離された遺伝子が形態形成の上で担う具体的な機能は、どのようにすれば知る ことができるであろうか。遺伝子の単離に至る筋道にも増して、遺伝子の機能の解明は困 難な課題である。遺伝子を単離できた時点では、変異体、遺伝子とかたち、の結びつきが 理解されたとは言いがたい（図 3）。遺伝子の塩基配列から、どのようなことをする遺伝 子か判明することも確かにあるが、それ単独で、その遺伝子が形態形成に、具体的にどの ように働いているのかを知ることは、まず不可能である。たとえばダイコンを実験材料に、 植物体が小さくなる変異体を単離し、それに対応する遺伝子を同定した結果、それがある 特定の脂肪酸分子の合成酵素遺伝子だったとしょう。この場合は遺伝子から細胞へ、そし て形への筋道がある程度描け、理解ができる。しかしその遺伝子が、タンパク質のリン酸 化酵素だったとすると、これはこの遺伝子だけを解析しても、理解は進まない。注目する 形質に、リン酸化による制御系が関わっていることはそれで判明するが、その遺伝子から 翻訳されるリン酸化酵素が、どのタンパク質をリン酸化するのか、その結果何が生じるの か、その解明を待たない限り、遺伝子から形態へのつながりは生じたことにならない。
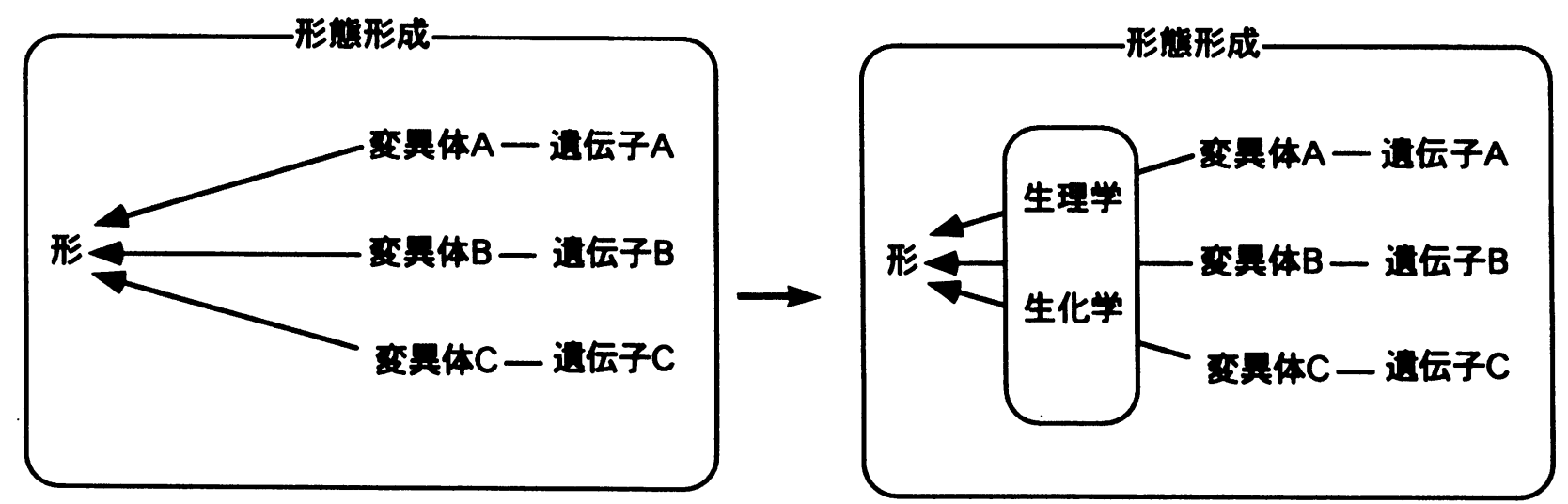

図 3 形態形成の過程を理解するためには、遗伝子と形との間をつなぐことが必要である 
今までのところ、形態形成に関連した遺伝子として単離された遺伝子の多くは、不思議 なくらい、リン酸化酵素や転写因子などの、他の遺伝子や遺伝子産物を標的として働く夕 ンパク質をコードしている例が多い。特に。特定の形態形成の鍵となる遺伝子は、このよ うな、他の遺伝子に働きかけるタイプの機能を有している可能性が高い。そうした場合、 形態形成の仕組みについて本当に理解するためには、そのターゲットとなっている下流の 遺伝子群の解明が必須である。

また、単離された遺伝子単独では理解が深まらないケースは、その他にも多い。すでに 古くから研究の歴史が積み重ねられてきた生物現象に関しては、関連遺伝子の単離は、更 なる理解の突破口にはなっても、それ自体からはあまり新たな情報が得られないことも、 充分あり得る。たとえばカブを実験材料に、植物全体が細長く伸びるような変異体を単離 し、解析した結果、細胞伸長が促進されていることがわかったとする。そこで、さらにそ れに対応する遺伝子を単離したところ、それがフィトクロム遺伝子だったとしよう。この 場合も、確かに遺伝子から形への筋道、つまりフィトクロムから細胞伸長、ひいては器官 の伸長、という筋道は描けるが、実はそれは遺伝子の単離以前から描けていた筋道でしか ない。フィトクロムが光を受容し、その結果、植物が光形態形成を行なっていることは、 分子遺伝学以前から、生理学と生化学とによる解析の結果、すでにわかっていたことだか らである。このように、形態に関わる遺伝子の単離ができても、理解は本質的に深まらな いケースはままあるわけである。しかし、遺伝子を単離したことで、手がかりをつかんだ ことには違いがない。この場合で言えば、従来、フィトクロムから先、どのように光情報 が伝達されているのかの解析は、生理学的・生化学的・生物物理学的解析からわかる範囲 ではすでにほとんどやり尽くされた感がある。したがって遺伝子そのものを手にしたこと で、新たな打開策を導入できる、という点では、この遺伝子単離は重要な意味を持ちうる と言えよう。

ではどうやって、遺伝子の機能を知ればよいのか？それはケースバイケースである。唯 一言えることは、遺伝子の理解を深めようとすればするほど、援用すべき技術は複合領域 にわたってゆくだろう、ということである。特に、ここで問題としている形態形成の仕組 みに対する理解のためには、形態学のみでも、また分子遺伝学のみでも不十分である。

葉の展開と発生遺伝学、生化学の連結

さて本総説の本題は葉の形態形成のメカニズムをどのように理解するか、であるから、 ここで、以上の議論の具体例として、私たちの行なってきた研究について簡単に振り返っ てみたい。ここではそのうちに、葉の展開過程の解析について、途中経過ながら簡単にご 紹介する。

まず最初は、葉の外形の制御について理解しようと、既知の突然変異体angustifolia(an) 変異体を巨視的に解析した。その結果、an変異体は葉の幅は短くなっているものの、長さ には異常がない(Tsukaya et al., 1994; Tsuge et al., 1996)ことが判明したので、葉の横幅の制 御と長さの制御は独立なのではないかと仮定を立てた。そこで、葉の横幅は正常で、縦の 長さが短い変異体をスクリーニングした。その結果得られた変異体がrotundifolia3(rot3)変 異体である(Tsuge et al., 1996)。an変異とrot3変異とは独立にはたらき、2 重変異体は縦に 
も横にも短い葉を形成したので、当初の仮定は正しかったのではないかと考えた。

そこで、各遺伝子の機能を知るために、まず解剖学的な解析を両変異体に対して行なっ たところ、両变異体とも、葉を構成する細胞の極性伸長に欠損があることが判明した。し たがって、AN遺伝子とROT3遺伝子とは、それぞれ葉の細胞の、横と縦の伸長を司ってい るのではないか、と推論した(Tsuge et al., 1996)。ここまでは純粋な発生遺伝学的解析であ る。

さらに、そうであるとすれば、植物細胞の極性伸長の制御について従来わかっていたこ とから想像するに、AN遺伝子とROT3遺伝子とは、細胞壁に関連した制御系ではないかと 思われたので、細胞壁のセルロース微細瀻維の方向性を制御することが推定されている細 胞表層微小管の配向、およびセルロース微細繊維に対する架橋分子の構成比について解析 を行なった。生理学的、生化学的解析の導入を図ったわけである。その結果、an変異と rot3変異とがそれぞれの過程に対して異常をもたらしていることが判明した(Tsukaya et al., submitted)。AN遺伝子とROT3遺伝子とが直接、注目している過程を制御しているのかどう かは、まだ判断が難しいが、より多くの手法を組み合わせて解析を進めることで、その点 も明らかになってゆくものと期待している。分子遺伝学的手法として、遺伝子単離も試み 始めているが、ただし、これもさきにあげたような難問に当たる可能性は高い。

もし今想像しているように、葉の全形の制御は、葉の細胞の細胞表層微小管の配向制御 や、およびセルロース微細繊維に対する架橋分子の構成比の制御のもとにあるとしょう。 そしてそれぞれに対応する遺伝子が単離できたとする。しかし細胞表層微小管の配向が、 どのようにして決められているのかについては、この問題を専門に研究しているグループ が世界中にいくつもありながら、まだよくわかっていない。したがって、遺伝子が単離さ れらば、細胞表層微小管の配向制御に関わる一員が明らかになったということで意義は深 いと思われるが、具体的にどのようにして細胞表層微小管の配向制御を行なっているかを 知るためには、細胞骨格の研究者と密接に連絡を取り合いながら解析を進めてゆくことが 必須であろう。また、セルロース微細繊維に対する架橋分子の構成比に関しても、おそら く架橋分子の合成醳素遺伝子や、その調節遺伝子が関与しているものと思われるが、これ はまた、架橋分子が細胞壁のゆるみとどう具体的に関与しているのかが、まだよくわかっ ていないため、生化学的・生物物理的な解析をさらに進める必要があるだろう。

すなわち、形態形成の仕組みを本当に理解しょうと思うならば、分子遺伝学と形態学と からなる発生遺伝学を、さらに拡充する必要がある。生理学、生化学、生物物理学などあ らゆる解析手法を取り込んでゆくことが必要であろう。ここまで来ると、1つの研究グル ープがどこまでやれるのか、またやるべきなのか、その選択にも迫られることになろう。 これはまたこの種の研究の 1 つの難問である。

葉形態の進化との結びつきへ

ところで、今まで述べてきた戦略では、実はアラビドプシスならアラビドプシスの、1 つの植物種における形態形成の仕組みしか、分かったことにならない。おそらく基本的な 仕組みは、双子葉植物の間で共有されているものと考えられるが、しかし基本的な部分だ けの理解では、なかなか形態の進化の問題は理解できない。もっとも例外はあって、例え 
ば、最近、花の対称性を放射総称から左右対称に変化させる遺伝子がキンギョソウから単 離された。この遺伝子と相同な遺伝子がどのようになっているかを、いろいろな分類群で 調べたところ、調べられた限りにおいてすべてのケースで、遺伝子の変異と、花の対称性 の変化とが一致していた(Dr. E. Coen, personal communication)。驚くべきことに、キク科植 物の筒状花と舌状花との違いも、この遺伝子で説明がつくという。また、近年、MADS遺 伝子の系統進化と、植物の花器官の進化との対応が議論されている（長谷部光泰ら、 personal communication）。これも興味深いことには、遺伝子重複と機能の分化、花器官の 進化が対応しそうだという。基本的形態の進化については、あるいはこのような此較分子 遺伝学とでも称されるべき方法によって、解明が進むかもしれない。

それでなくても、形態進化の仕組みを理解しようと考えるならば、アラビドプシスなど のモデル植物で得られた、形態形成の背景にある分子遺伝学的な知見を取り込んでゆくこ とは必須である。そのためには、進化生物学の領域においても、実験生物学の手法を取り 込み、特に遺伝学的な知見を深めてゆくことが必須である。まずは、注目する形態形質に ついて祖先形質と派生形質との間に、いくつの遺伝子变異が関わっているのか、古典遺伝 学的な知見を基礎として蓄積していくことが必要である。意外なほど、そのような視点に 基づいた研究はまだそしい。逆にモデル植物であるアラビドプシスやキンギョソウからは、 1 遺伝子座の变異で、いかに劇的な形態変化が生じうるか、多くの実例を提供しつつある。 いかにして、モデル植物より得られた知見を形態進化の理解に応用してゆくかの議論は、 他に書いた(Tsukaya, 1995)ので、ここでは省略するが、モデル植物から明らかになってゆ く形態形成の制御系の仕組みを、野生植物の形態進化と結びつけてゆくことができれば、 それはきっと実り豊かなものとなるであろう。

謝辞

本総説の背景となった研究に関して、柘植知彦博士、内宮博文教授、西谷和彦助教授のご 協力、ご助言を頂いた。また文部省科学研究費補助金・重点領域研究の研究補助を受けた。 記して感謝する。

文献

Avery, G.S.Jr. (1933). Structure and development of the tobacco leaf. Amer. J. Bot. 20: 565-592. Dale, J.E. (1988). The control of leaf expansion. Annu. Rev. Plant Physiol. Plant Mol. Biol. 39: 267-295.

Maksymowych, R. (1963). Cell division and cell elongation in leaf development of Xanthium pensylvanicum. Amer. J. Bot. 50: 891-901.

Meyerowitz, E.M. and Pruitt, R.E. (1985). Arabidopsis thaliana and plant molecular genetics. Science. 229: 1214-1218.

Poethig, R.S. and Sussex, I.M. (1985). The developmental morphology and growth dynamics of 
the tobacco leaf. Planta. 165: 158-169.

Tsuge, T., Tsukaya, H., Uchimiya, H. Two independent and polarized processes of cell elongation regulate leaf blade expansion in Arabidopsis thaliana (L.) Heynh. Development. 122 : 1589-1600.

Tsukaya, H. 1995. "The genetic control of morphogenesis in Arabidopsis and its relevance to the development of biodiversity.": In: Arai, R., Kato, M., and Doi, Y. eds. "Biodiversity and Evolution" pp.253-265. The National Science Museum Foundation, Tokyo

Tsukaya, H., Naito, S., Redei, G.P., Komeda, Y. (1993). A new class of mutations in Arabidopsis thaliana, acaulis1, affecting the development of both inflorescences and leaves.

Development 11 8: 751-764.

Tsukaya, H., Tsuge, T., Kim, G.-T., and Uchimiya, H. (1995). Genetic analysis of cell-expansion processes in leaves of Arabidopsis thaliana. Plant Morph. 7: 11-18

Tsukaya, H., Tsuge, T., and Uchimiya, H. (1994). The cotyledon: a superior system for studies of leaf development. Planta 195: 309-312. 